\title{
Making Students Carefully Catering Environment Through Adiwiyata Program
}

\author{
Hengkang Bara Saputra \\ Faculty of Teacher Training and Education \\ Ahmad Dahlan University \\ Yogyakarta, Indonesia \\ hwmpaiuad@gmail.com
}

\author{
Hendro Widodo \\ Faculty of Teacher Training and Education \\ Ahmad Dahlan University \\ Yogyakarta, Indonesia \\ hwpgsd1960@gmail.com
}

\begin{abstract}
This article is based on the low level of environmental cares among students and environmental education in schools is not implemented maximally. Schools as educational institutions become a strategic and effective place to realize students who care about the environment. In the Adiwiyata Program, the character of environmental care can be instilled in students through activities such as waste utilization and processing, flood prevention, Gertak Semut (Simultaneous Picking Movement), Simutlis (Ten Minutes for School Environment), clean Friday, healthy canteens and schools. participatory and sustainable by the school community.
\end{abstract}

Keywords - Character, Care for the Environment, Adiwiyata Program

\section{INTRODUCTION}

Humans and the environment are like two sides of an inseparable currency. Humans live in an environment that surrounds them interacting with the natural environment, so whether or not the natural environment is affected by human quality. It cannot be denied that environmental damage can be caused by humans who do not care about the environment and humans who do it can be because education in itself is not well planted. As Darajat argues that the cause of environmental damage due to Islamic education is not well planted and causes the failure to carry out religious teachings properly [1]. Although experts disagree about the causes of damage, no one has denied that humans are one of the causes of damage to nature [2].

Awareness and concern for the environment by not taking actions that damage the environment needs to be instilled early through environmental education. Environmental Education (PLH) according to the UNESCO convention in Tbilisi (1997) is a process that aims to create a world community that has concern for the environment and cares for the problems associated with it and has the knowledge, motivation, commitment and skills to work, both individually and collectively in finding alternatives or providing solutions to existing environmental problems and to avoid the emergence of new environmental problems [3].

Schools as educational institutions become a strategic and effective place to realize students who care about the environment. Through formal institutions (schools), the learning process of environmental education can be carried out, not only on the cognitive domain, but also how students can feel caring and not take environmental damage. Environmental education is part of character education. Through this environmental education, students are expected to participate in preservation and rescue by knowing, developing attitudes and taking action to love the environment. However, various increasingly uncontrolled environmental problems indicate that Environmental Education has not succeeded in shaping human characters who care about the environment. Daryanto and Suprihatin said that the failure occurred due to a number of weaknesses in Environmental Education. The failure cannot be separated from the following: [4]

First, there is still a low level of community participation to play a role in environmental education, due to a lack of understanding of the problems of environmental education, low levels of ability or skills, and a lack of community commitment in solving these problems. Second, the understanding of education actors on environmental education is still limited. In the path of formal education, there is still an assumption that environmental education is not so important. Third, the material and methods of implementing environmental education are deemed inadequate, and less applicable, so that the understanding of the target group regarding environmental conservation is not intact. Fourth, facilities and infrastructure in environmental education have not received sufficient attention. Facilities and infrastructure for environmental education are often misinterpreted as hightech physical facilities so that they become an inhibiting factor in the growth of motivation in the implementation of Environmental Education. Fifth, the lack of the ability of the government to allocate and increase the budget for environmental education, so that the implementation of Environmental Education, in various agencies is not optimal. Sixth, the lack of coordination between relevant agencies and education actors led to the lack of development of Environmental Education. This can be seen in the Environmental Education movement (formal and non-formal / informal) which is still sporadic, not synergistic and overlapping.

There are many ways that can be done to provide a good understanding of the environment for each individual, such as information, counseling, guidance, and education (formal and non formal from kindergarten, elementary school to university)[5]. Similarly Hamzah states that the character of 
caring for the environment is not entirely the innate talent and instinct, but also the result of an educational process in the broadest sense. Therefore, through the process of environmental education in schools, the character of environmental care can be instilled [6].

On the other hand, one of the efforts to overcome the weaknesses in this Environmental Education, the Ministry of Environment in 2006 developed an environmental education program at the primary and secondary education levels through the Adiwiyata program. The Adiwiyata program is one of the programs of the Ministry of Environment in order to encourage the creation of knowledge and awareness of school residents so that it becomes a character of environmental care in an effort to preserve the environment [7].

Therefore, the adiwiyata program is expected to be a means to realize students with environmental care, because through this program, all school citizens are required to participate in school activities towards a healthy school environment and avoid negative environmental impacts, through activities such as waste utilization and processing, flood prevention, Gertak Semut (Simultaneous Picking Movement), Simutlis (Ten Minutes for School Environment), clean Friday, healthy canteens and schools, and so on.

\section{DISCUSSION}

\section{Character}

Etymologically, the character in the Popular Scientific Dictionary means character, character, character or habit [8]. Koesuma states that character is the same as personality. Personality is considered as a characteristic or characteristic or characteristic of a person originating from the formations received from the environment, such as family, community, or it can also be an innate carry from birth [9]. The same thing was stated by Sulistyowati that character can be interpreted as character, character, character and personality that is formed from the results of internalization of various virtues that are used as a basis for the way of thinking and thinking, acting, and acting [10].

According to Aqib and Sujak, characters come from Greek which means "to mark" or mark and focus on how to apply the value of goodness in the form of actions or behavior, so that people who are dishonest, cruel, greedy, and behavior other ugly people are said to be ugly. Conversely, people whose behavior is in accordance with moral principles is called noble character [11]. In terms of terminology, the meaning of character is stated by Lickona, namely "A reliable inner disposition to respond to situations in a morally good way." He added, "Character so conceived has three interrelated parts: moral knowing, moral feeling, and moral behavior ". According to Lickona, the noble character (good character) includes knowledge of goodness, then raises commitment (intention) towards goodness, and ultimately really does good. In other words, character refers to a series of knowledge (cognitives), attitudes (attitides), and motivations (motivations), as well as behaviors and skills [12].
Gunarto describes character as the values of human behavior that relate to God Almighty, oneself, fellow human beings, environment, and nationality which are manifested in thoughts, attitudes, feelings, words, and actions based on religious norms culture and national values that are actualized in daily life become inherent habituation [13]. Based on the understanding of the characters above, it shows that characters can be identified with the character, morals, morals and personality that a person has and that distinguishes them from others. People with character mean people who have morals, character, morals and personality that can be manifested in good and bad actions that are actualized in daily life into an inherent habit.

\section{Caring for the Environment}

Human life cannot be separated from the environment, and humans in carrying out their activities are sometimes less friendly with the environment because they do actions that are less commendable by showing their indifference to the environment. Whereas human beings are cultured and ethical, including in their environment, because every human being must be able to regulate his relationship with the environment in the form of human wisdom in responding to and treating his environment well or caring for the environment.

Caring for the environment is an attitude and action that always strives to prevent damage to the surrounding natural environment and develop efforts to repair the natural damage that has already occurred [14]. According to AlAnwari caring for the environment is an attitude and action that always strives to prevent damage to the surrounding natural environment and the development of efforts to repair the natural damage that has occurred. The meaning is environmental care is a form of individual mental attitude which is manifested in loving environmental behavior (preserving and preserving the environment) [15].

Sue (Tamara, 2016: 42) explained that "caring for the environment is general attitudes towards environmental quality which is manifested in the willingness to express actions that can improve and maintain environmental quality in every environment-related behavior". If environmental care can be expressed by actions, students who care about their environment will always preserve the environment [16]. The same thing also expressed by Daryanto and Darmiatun caring for the environment is the attitude and actions that always try to prevent damage to the surrounding natural environment, and develop efforts to repair the natural damage that has occurred [17].

The word "environmental care" in community life is more defined as a caring reaction to one's environment. For example, it does not damage the natural environment by always maintaining the environment, or in other words must always maintain and preserve the environment so as not to become damaged, polluted and even become extinct. With an environmental care attitude, a clean and beautiful environment will be created [18].

Environmental care including attitude categories is also reinforced in Muchlas's statement Samani and Hariyanto dividing attitudes and behaviors into five ranges as follows: a) 
attitudes and behavior in relation to God, b) attitudes and behaviors in relation to oneself, c) attitudes and behavior in relation to family, d) attitudes and behavior in relation to society and nation, and e) attitudes and behavior in relation to the surrounding environment. Based on this opinion, caring for the environment includes attitudes related to the surrounding environment [19].

The Ministry of National Education Central Curriculum Research and Development Agency mentions environmental care indicators at the primary school level, namely for grade 1-3 students with indicators such as defecating and defecating in the toilet, throwing garbage in its place, cleaning the school yard, not picking a flower in the school garden, keeping the house clean. As for indicators for grade 4-6 students, namely cleaning the toilets, cleaning the trash, cleaning the school environment, beautifying classes and schools with plants, and taking care of the garden in the school yard. Narwanti mentions the implementation of the character of environmental care in schools for students can be seen from the following activities: a) cleanliness of the classrooms maintained, b) providing organic and non-organic trash cans, c) saving in the use of practical materials, and ) handling of chemical waste from practical activities [20].

Based on the above opinion, caring for the environment is a unity between the thoughts, attitudes and actions of individuals towards the environment by not doing damage but preserving and repairing the damage to nature. The character of environmental care is an effort to instill environmentalbased character values in participants both in the learning process and outside the learning process so that students have sensitivity and love for the environment. Planting character education for the environment in schools must be adjusted to the level of education, because every level of education has different indicators that are in accordance with the stages of development.

\section{Adiwiyata Program}

\section{a. Understanding Adiwiyata}

The word Adiwiyata comes from two words, namely "Adi" and "Wiyata". Adi means big, great, good, ideal, and perfect. Wiyata has the right meaning where a person gets knowledge, norms and ethics in social life. Adiwiyata is defined as "a good and ideal place where all knowledge and various norms and ethics can be obtained that can be the basis of human beings towards the creation of our welfare and towards the ideals of sustainable development" [21].

According to the Regulation of the Minister of Environment No. 02 of 2009 concerning the Implementation of the Guideline of the Adiwiyata Program article 1 that adiwiyata is a good and ideal school as a place to obtain all knowledge and various norms and ethics that can be the basis of humanity. sustainable development. Adiwiyata program is one of the programs of the Ministry of Environment in order to encourage the creation of knowledge and awareness of school residents so that it becomes a character of environmental care in an effort to preserve the environment [22].
Creating an environmentally sound school certainly has a clear correlation in creating school environment conditions that are green, comfortable, healthy, clean and so on with effective teaching and learning activities so that ultimately the goals of education can be achieved with satisfactory results with high graduates' quantity along with good quality. An environmentally sound school is not only a green, comfortable, healthy and clean school, but the school environment functions as a laboratory, has aesthetic value, economic value, a school that is environmentally friendly and schools that support the preservation and saving of the environment. An environmentally sound school is a school that utilizes the environment as a source and place for teaching and learning activities as well as paying attention to the condition of the school environment so that it becomes a green school with neat, beautiful, shady and clean. In addition to supporting the process of teaching and learning activities in environmentally sound schools, it also fosters caring and responsive attitudes towards environmental problems that are now vulnerable to occur [23].

Based on the above description, it can be concluded that adiwiyata school is a school that utilizes the environment as a source and place of teaching and learning activities and also pay attention to the environmental conditions of school schools that are environmentally friendly and support of the environment so that it becomes a green school with neat, beautiful, shady and clean.

\section{b. Objectives and Adiwiyata Principles}

The aim of the Adiwiyata program is to realize school citizens who are responsible for environmental protection and management through good school governance to support sustainable development. Through the Adiwiyata program with various awards, making schools compete to be the best in terms of environmental conservation. This activity has a good impact on environmental sustainability in the future. Because the school environment is an environment that greatly influences the application of human life.

By carrying out the Adiwiyata program will create school citizens, especially students who are caring and environmentally cultured, while supporting and realizing human resources that have national character towards economic, social and environmental development in achieving sustainable development in the region [24]. The implementation of the Adiwiyata Program is placed on two basic principles, namely: 1) participatory; the school community is involved in school management which covers the entire planning, implementation and evaluation process according to responsibilities and roles, and 2) sustainable; all activities must be carried out in a planned and continuous manner comprehensively. Both principles are used as the basis for the implementation of the adiwiyata program so that the implementation of the adiwiyata program involves all school residents and is carried out continuously. 
c. Adiwiyata Program to Realize Students with Environmental Care Characteristics

Caring for the environment is part of the character value that can be instilled in students in school. Referring to the Guide to Character Education Implementation that caring for the environment is one of the very important character values introduced and internalized into character education in schools. Schools have a duty to shape the character of environmental care for students. Character will be formed from the attitudes and actions carried out continuously so that the school has an obligation to instill a sustainable environmental care attitude [25].

Mustakim asserted that schools should play their role in shaping environmental awareness. There needs to be character formation for the environment in students. This character can be started from trivial issues, such as providing adequate trash cans, to formulating an action plan on environmental awareness programs. Through the formation of this character, it is expected that a generation that has environmental concerns will be born. One school program that can be done to instill the character of caring for the environment is through the adiwiyata program [26].

One of the principles in the adiwiyata program is participatory-based environmental activities, meaning that all school residents are involved in managing the school environment according to their respective responsibilities and roles. Nofijantie provides an example of participatory environment-based activities, namely [27]:

1) Carry out planned environmental protection and management activities for school residents, including: a) maintaining and caring for buildings and school environments by school residents, such as class picket activities, Gertak Semut activities (Simultaneous Picking Movement), Friday clean, work mass service, and maintaining parks.

2) Utilizing school land and facilities according to the principles of protection and management of the Living Environment (impacts caused by school activities), including maintenance of parks, medicinal plants (toga) and waste management.

In addition, participatory clean environmental activities include: schools doing environmental hygiene activities with surrounding communities, schools seeking outside party sponsors to conduct environmental activities, c) schools of extra curricular and curricular holding activities in order to foster awareness of students behave / culturally care about the environment, d) schools hold a socialization activity on understanding and awareness of the environment to school residents, e) schools prohibit food vendors who do not meet hygiene and health standards and do not maintain the cleanliness of the environment [28].

Furthermore Widodo explains in the school adiwiyata program, a clean and orderly environmental culture that is reflected in the environmentally sound school regulations, namely: a) every school is obliged to maintain cleanliness in the school environment, b) every school Every school member is obliged to collect and put waste into the trash can in accordance with the type of waste (paper, plastic and organic), d) every school member is obliged to use water by saving the tap and closing the faucet after use, e) every school member is obliged to maintain cleanliness (WC), f) every school citizen is dressed cleanly, neatly in accordance with the uniform regulations set by the school, g ) school residents are prohibited from smoking in the school environment, h) school residents are prohibited from scribbling walls and learning facilities, i) scheduled students each class cleaning the school environment for 10 minutes (SEMUTLIS Program).

\section{Conclusion}

Caring for the environment is part of the character value that can be instilled in students in school. Schools have a duty to shape the character of environmental care for students. Character will be formed from the attitudes and actions carried out continuously so that the school has an obligation to instill a sustainable environmental care attitude. Through the Adiwiyata program, all school residents are involved in utilizing the environment as a source and place for green teaching and learning activities that are neat, beautiful, comfortable, shady, and clean. Through the adiwiyata program, a clean and orderly environmental culture will be created which can be reflected in the environmentally sound school regulations so that all school residents have a concern for the love of the environment.

\section{References}

[1] Aziz, Erwati. Upaya Pelestarian Lingkungan Hidup Melalui Pendidikan Islam. Yogyakarta: Pustaka Pelajar. 2013

[2] Al-Anwari, Amirul Mukminin. "Strategi Pembentukan Karakter Peduli Lingkungan di Sekolah Adiwiyata Mandiri". TA'DIB, Vol. XIX, No. 02, Edisi November 2014"

[3] Desfandi, Mirza. "Mewujudkan Masyarakat Berkarakter Peduli Lingkungan Melalui Program Adiwiyata". Sosio Didaktika: Social Science Education Journal, 2 (1), 2015, 31-37

[4] Daryanto dan Suprihatin, Agung. Pengatar Pendidikan Lingkungan Hidup. Yogyakarta: Gava Media, 2013

[5] Yafie, Ali. Merintis Fiqh Lingkungan Hidup. Jakarta: Ufuk Press, 2006.

[6] Hamzah, Syukri. Pendidikan Lingkungan: Sekelumit Wawasan Pengantar. Bandung: Refika Aditama, 2013

[7] Kemendiknas. Panduan Pelaksanaan Pendidikan Karakter, Jakarta: Badan Penelitian dan Pengembangan Pusat Kurikulum dan Perbukuan, 2011

[8] Maulana, Achmad dkk. Kamus Ilmiah Populer. Yogyakarta: Absolut, 2004.

[9] Koesuma, Doni A. Pendidikan Karakter Strategi Mendidik Anak diZaman Global. Jakarta: Grasindo, 2010.

[10] Sulistyowati, Endah. Implementasi Kurikulum Pendidikan Karakter. Yogyakarta: Citra Aji Parama, 2012.

[11] Aqib Zainal, dan Sujak. Pandaun dan Aplikasi Pendidikan Karakter, Bandung: Yrama Widya, 2012

[12] Lickona, Thomas. Educating for Character. New York: Bantams Books, 1991.

[13] Gunarto. Implementasi Pendidikan Budi Pekerti. Jakarta: Raja Grafindo Persada. 2004

[14] Puskur. Pengembangan Pendidikan Budaya dan Karakter Bangsa. Jakarta: Badan Litbang Kementrian Pendidikan Nasioanal, 2010.

[15] Al-Anwari, Amirul Mukminin. "Strategi Pembentukan Karakter Peduli Lingkungan di Sekolah Adiwiyata Mandiri". TA'DIB, Vol. XIX, No. 02, Edisi November 2014 
[16] Tamara, Riana Monalisa. Peranan Lingkungan Sosial Terhadap Pembentukan Sikap Peduli Lingkungan Peserta Didik Di SMA Negeri Kabupaten Cianjur. Gea, Jurnal Pendidikan Geografi, Volume 16, Nomor 1, April 2016

[17] Daryanto dan Suprihatin, Agung. Pengatar Pendidikan Lingkungan Hidup. Yogyakarta: Gava Media, 2013

[18] Tamara, Riana Monalisa. 2016. Peranan Lingkungan Sosial Terhadap Pembentukan Sikap Peduli Lingkungan Peserta Didik Di SMA Negeri Kabupaten Cianjur. Gea, Jurnal Pendidikan Geografi, Volume 16, Nomor 1, April 2016

[19] Samani, Muchlas, Hariyanto. Pendidikan karakter. Bandung: PT Remaja Rosdakarya. 2012

[20] Narwanti, Sri. 2011. "Pendidikan Karakter Pengintegrasian 18 Nilai Pembentuk Karakter dalam Mata Pelajaran". Yogyakarta: Familia

[21] Susy HR Sadikin, dkk. 2011. Panduan Adiwiyata. Jakarta: KerjasamaKementerian Lingkungan Hidup dengan Kementerian Pendidikan dan Kebudayaan

[22] Widodo, Hendro. 2017. "Budaya Sekolah Adiwiyata (Studi Kasus Di SD Muhammadiyah Bodon Bantul)". Tajdidukasi, Volume VII, No. 1 Januari 2017

[23] Mansyur, Zaini. 2014. Strategi dari Dinas Pendidikan Kota Samarinda dalam Mewujudkan Sekolah Berwawasan Lingkungan Khususnya di Kecamatan Sungai Kunjang. eJournal Ilmu Pemerintahan, 2014, 2 (2) : 2767-2781. ejournal.ip.fisip-unmul.ac.id

[24] Desfandi, Mirza. "Mewujudkan Masyarakat Berkarakter Peduli Lingkungan Melalui Program Adiwiyata". Sosio Didaktika: Social Science Education Journal, 2 (1), 2015, 31-37

25] Kemendiknas. Panduan Pelaksanaan Pendidikan Karakter. Jakarta: Badan Penelitian dan Pengembangan Pusat Kurikulum dan Perbukuan, 2011.

[26] Mustakin, Bagus. 2011. Pendidikan Karakter Membangun Delapan Karakter Emas Menuju Indonesia Bermartabat. Yogyakarta: Samudra Biru

[27] Nofijantie, Lilik. "Menanamkan Nilai Karakter Peduli Lingkungan Melalui Pendidikan Lingkungan Hidup Tantangan bagi FITK". Prosiding Halaqoh Nasional \& Seminar Internasional Pendidikan Islam. Disampaikan dalam Haflah Miladiyah FTK ke-25 di Hotel UTAMI Surabaya

[29] Widodo, Hendro. 2017. "Budaya Sekolah Adiwiyata (Studi Kasus Di SD Muhammadiyah Bodon Bantul)". Tajdidukasi, Volume VII, No. 1 Januari 2017 